\title{
2-MERCAPTOETHYLAMINE AS A MASKING AGENT FOR THE COMPLEXOMETRIC DETERMINATION OF PALLADIUM(II) IN CATALYSTS, ALLOYS AND COMPLEXES
}

\author{
PRAKASH SHETTY ${ }^{l, *}$ AND A. NITYANANDA SHETTY ${ }^{2}$
}

\author{
${ }^{1}$ Department of Chemistry, Manipal Institute of Technology (Manipal University), Manipal-576104. Karnataka, India. \\ ${ }^{2}$ Department of Chemistry, National Institute of Technology, Karnataka, Surathkal -574157. India.
}

(Received: November 28, 2007 - Accepted: March 25, 2008)

\begin{abstract}
A simple, rapid and accurate complexometric method for the determination of palladium in the presence of other metal ions is described, based on the selective masking ability of 2-mercaptoethylamine (MEA) towards Pd(II). Palladium(II) along with other associated metal ions present in a given sample solution is first complexed with an excess of EDTA and the surplus EDTA is titrated with zinc sulphate solution at pH 5-6 (acetic acid-sodium acetate buffer) using xylenol as indicator. A known excess of $0.2 \%$ aqueous solution of MEA is then added to displace EDTA from Pd(II)-EDTA complex and swirled well. The released EDTA is again titrated with zinc sulphate solution as before. The method works well in the range $2-20 \mathrm{mg}$ of palladium(II) with the relative error \pm 0.27 and the relative standard deviation $<0.35 \%$. The effect of the presence of various diverse ions on the accuracy of the results has been studied. The method has been satisfactorily applied for the determination of palladium in catalysts, alloys and complexes.
\end{abstract}

Key words: palladium determination, complexometry, masking reagent, 2-mercaptoethylamine

\section{INTRODUCTION}

Palladium finds extensive applications as a catalyst in hydrogenation and dehydrogenation reactions. It also tends to retard the formation of silver sulphide and has been become a common component of medicinal devices and dental alloys. The high melting point of Pd and its alloys provide high resistance to corrosion, and hence it is widely used in electrical contacts. Metallic Pd and its alloys serve as substitutes for Pt in jewellary. Since it is much lighter than Pt, Pd has been used for the construction of astronomic and sensitive instruments. It was thus considered worthwhile to explore the possibilities of developing a simpler, selective, rapid and accurate analytical method for the determination of Pd(II) in various samples. In this context, an attempt has been made to explore the utility of 2-mercaptoethylamine as a selective masking reagent for the complexometric determination of $\mathrm{Pd}(\mathrm{II})$.

The earlier reported methods for the complexometric determination of
Pd(II)employed dimethylglyoxime ${ }^{1}, 1,2,3$-benzotriazole ${ }^{2}, 1,10$-phenanthroline ${ }^{3}$, thiourea ${ }^{4}$ and pyridine ${ }^{5}$ as masking reagents. All these methods involve time consuming steps like heating, cooling or extraction and hence are not rapid. Several common metal ions show interference in 4-amino-5-mercapto3-propyl-1, 2, 4-triazole ${ }^{6}$, thiosemicarbazide ${ }^{7}$, and 4-amino-3-mercapto-1, 2, 4-triazine-5-one method ${ }^{8}$. Thiocyanate ${ }^{9}$, hydroxylamine hydrochloride ${ }^{10}$, N-(2-pyridyl) thiourea ${ }^{11}$, DL-cystein ${ }^{12}$, 3-mercaptopropane-1, 2-diol ${ }^{13}$, 2-mercaptopropionyl glycine ${ }^{14}$ and thioacetamide ${ }^{15}$ are some of the other reported masking agents for palladium.

We are now reporting the application and advantages of 2mercaptoethylamine as a selective masking reagent for the complexometric determination of $\mathrm{Pd}(\mathrm{II})$. The proposed method is free from various common interfering ions and does not require any heating or extraction step.

A comparison of the proposed method with other reported methods for palladium determination is given in Table 1.

Table 1. Comparison of MEA with reported masking agents for Pd determination

\begin{tabular}{|c|c|c|c|}
\hline Masking agent & Interference & Comments & Ref. \\
\hline Pyridine & $\mathrm{Hg}(\mathrm{II}), \operatorname{Ir}(\mathrm{III}), \operatorname{Pt}(\mathrm{IV}), \mathrm{Mn}(\mathrm{II})$ & $\begin{array}{l}\text { Requires heating. } \\
\text { Reagent is water insoluble }\end{array}$ & 5 \\
\hline $\begin{array}{l}\text { 4-amino-5-mercapto-3n- propyl-1,2,3- } \\
\text { triazole }\end{array}$ & $\begin{array}{l}\operatorname{Ag}(\mathrm{I}), \mathrm{Hg}(\mathrm{II}), \mathrm{Sn}(\mathrm{II}), \mathrm{Mn}(\mathrm{II}), \mathrm{Fe}(\mathrm{II}), \mathrm{Sb}(\mathrm{III}) \\
\mathrm{Al}(\mathrm{III}), \mathrm{Tl}(\mathrm{III})\end{array}$ & $\begin{array}{l}\text { Works for } 0.5-5 \mathrm{mg} \text { of Pd. } \\
\text { Water insoluble reagent, which requires } \\
\text { preparation. }\end{array}$ & 6 \\
\hline Thiosemicarbazide & $\begin{array}{l}\mathrm{Cu}(\mathrm{II}), \mathrm{Fe}(\mathrm{II}), \mathrm{Sn}(\mathrm{II}), \mathrm{Hg}(\mathrm{II}), \mathrm{Tl}(\mathrm{III}), \mathrm{Bi}(\mathrm{III}), \\
\mathrm{Al}(\mathrm{III}), \mathrm{Cr}(\mathrm{III})\end{array}$ & & 7 \\
\hline 4-amino-3-mercapto -1,2,4-triazine-5-one & $\begin{array}{l}\operatorname{Ag}(\mathrm{I}), \mathrm{Hg}(\mathrm{II}), \mathrm{Sn}(\mathrm{II}), \mathrm{Mn}(\mathrm{II}), \mathrm{Fe}(\mathrm{II}), \mathrm{Sb}(\mathrm{III}) \\
\mathrm{Al}(\mathrm{III}), \mathrm{Tl}(\mathrm{III})\end{array}$ & $\begin{array}{l}\text { Works for } 0.5-5 \mathrm{mg} \text { of Pd. } \\
\text { Water insoluble reagent, which requires } \\
\text { preparation. }\end{array}$ & 8 \\
\hline Thiocynate & $\operatorname{Hg}(\mathrm{II}), \operatorname{Ir}(\mathrm{III}), \mathrm{Tl}(\mathrm{III}), \mathrm{Mn}(\mathrm{II}), \mathrm{Sn}(\mathrm{IV})$ & & 9 \\
\hline Hydroxylamine hydrochloride & $\mathrm{Hg}(\mathrm{II}), \mathrm{Cd}(\mathrm{II}), \mathrm{Cr}(\mathrm{III}), \mathrm{Al}(\mathrm{III}), \mathrm{Tl}(\mathrm{III})$ & Requires readjustment of $\mathrm{pH}$ & 10 \\
\hline N-(2-pyridyl thiourea) & $\mathrm{Hg}(\mathrm{II}), \mathrm{Cr}(\mathrm{III}), \mathrm{Tl}(\mathrm{III})$ & $\begin{array}{l}\text { Water insoluble reagent, which requires } \\
\text { preparation }\end{array}$ & 11 \\
\hline DL-cystein & $\mathrm{Cu}(\mathrm{II}), \mathrm{Hg}(\mathrm{II}), \mathrm{Tl}(\mathrm{III}), \mathrm{Zr}(\mathrm{IV}), \mathrm{Sn}(\mathrm{IV})$ & - & 12 \\
\hline 3-mercapto propane-1,2-diol & $\begin{array}{l}\mathrm{Hg}(\mathrm{II}), \mathrm{Tl}(\mathrm{III}), \mathrm{Cr}(\mathrm{III}), \mathrm{Bi}(\mathrm{III}), \mathrm{Sn}(\mathrm{IV}), \\
\mathrm{Mn}(\mathrm{II})\end{array}$ & - & 13 \\
\hline 2-mercapto propionyl glycine & $\mathrm{Cu}(\mathrm{II}), \mathrm{Hg}(\mathrm{II}), \mathrm{Tl}(\mathrm{III}), \mathrm{Cr}(\mathrm{III}), \mathrm{Sn}(\mathrm{IV})$ & - & 14 \\
\hline Thioacetamide & $\operatorname{Hg}(\mathrm{II}), \mathrm{Tl}(\mathrm{III}), \mathrm{Cr}(\mathrm{III}), \mathrm{Sn}(\mathrm{IV})$ & - & 15 \\
\hline 2-mercaptoethylamine (MEA) & $\begin{array}{l}\mathrm{Hg}(\mathrm{II}), \mathrm{Tl}(\mathrm{III}), \mathrm{Cu}(\mathrm{II}), \mathrm{Sn}(\mathrm{IV}) \\
\text { Interference from } \mathrm{Hg}(\mathrm{II}) \& \mathrm{Sn}(\mathrm{IV}) \text { can be } \\
\text { suitably avoided by premasking. }\end{array}$ & $\begin{array}{l}\text { Reagent is readily available } \\
\text { and soluble in water. Stringent conditions } \\
\text { like heating, readjustment of pH or } \\
\text { extraction are not required }\end{array}$ & $\begin{array}{l}\text { Present } \\
\text { method }\end{array}$ \\
\hline
\end{tabular}




\section{EXPERIMENTAL}

\section{Materials}

All the chemicals used were of analytical reagent grade. A stock solution of $\mathrm{Pd}(\mathrm{II})$ was prepared by dissolving $\mathrm{PdCl}_{2}$ (Merck) in minimum volume of concentrated $\mathrm{HCl}$ and making up to a known volume. The solution was standardized gravimetrically by dimethylglyoxime method ${ }^{16}$. Zinc sulphate solution $(0.01 \mathrm{M})$ was prepared by dissolving a known amount of zinc sulphate (Merck) in distilled water and standardized gravimetrically by salicylaldoxime method ${ }^{16}$. EDTA solution $(0.01 \mathrm{M})$ was prepared by dissolving the required amount of disodium salt of EDTA (Merck) in distilled water. A freshly prepared solution $(0.2 \%)$ of 2-Mercaptoethylamine (Fluka, Switzerland) in distilled water was used as the masking reagent. A freshly prepared aqueous solution of xylenol orange $(0.5 \%)$ was used as the indicator.

\section{Standard Procedure}

To a solution containing 2-20 mg of palladium(II) and varying amounts of diverse metal ions taken in a $250 \mathrm{~mL}$ conical flask, an excess of $0.01 \mathrm{M}$ EDTA was added. The solution was diluted to $60-70 \mathrm{~mL}$ with distilled water. The $\mathrm{pH}$ of the solution was initially adjusted between 4 and 5 by the drop-wise addition of diluted sodium hydroxide solution and finally to 5-5.5 with the addition of acetic acid-sodium acetate buffer. The surplus EDTA was titrated with $0.01 \mathrm{M}$ zinc sulphate solution using few drops of xylenol orange indicator to a sharp color change from yellow to red. To this, a $0.2 \%$ solution of MEA was added in required amounts and swirled well. The released EDTA was again titrated with the same $0.01 \mathrm{M}$ zinc sulphate solution as before. The second titre volume corresponds to the palladium content in the aliquot.

\section{RESULTS AND DISCUSSION}

\section{Masking property of 2-Mercaptoethylamine}

2-Mercaptoethylamine (MEA) is a potential bidentate ligand containing sulphur of mercapto group and nitrogen of amino group as donor atoms. It has been reported that MEA forms a strong 1:2 (M : L) neutral complex with $\mathrm{Pd}(\mathrm{II})$ by coordinating through deprotonated sulphur of thiol group and neutral nitrogen atom of amino group ${ }^{17,18}$. These results in the formation of a stable five membered chelate. This is very well in agreement with the consumption of two moles of MEA for each moles of palladium for the quantitative release of EDTA from Pd(II)-EDTA complex. The stability constant of the Pd(II)-EDTA complex is reported to be $26.4{ }^{19}$. However, no data on the stability constant of the Pd(II)-MEA are given in the literature. The quantitative release of EDTA from Pd(II)-EDTA complex by MEA at room temperature itself indicates that Pd(II)-MEA complex is more stable than Pd-EDTA complex under the experimental conditions employed.. This finding show that Pd(II) forms a stable complex with MEA than with EDTA and reverse is true with common metal ions. For instance, the EDTA complexes of $\mathrm{Zn}(\mathrm{II}), \mathrm{Ni}(\mathrm{II}), \mathrm{Cd}(\mathrm{II}), \mathrm{Pb}(\mathrm{II})$ are more stable $(\log \mathrm{K}=16.5,18.6,16.5,18.0)$ compared to their respective complexes with MEA $(\log \mathrm{K}=7.21,9.58,7.38,10.1)^{20}$.

\section{Effect of 2-Mercaptoethylamine concentration}

In order to find out the exact amount of MEA required for the quantitative release of EDTA from Pd-EDTA complex and the influence of excess reagent on the accuracy of the result, titrations were carried out with solutions containing $10.42 \mathrm{mg}$ of Pd(II) and varying amounts of $0.2 \%$ MEA solution added. From the plot (Fig. 1) of the volume of reagent added versus the recovery of Pd, it is clear that about $8 \pm 0.5 \mathrm{~mL}$ solution of $0.2 \%$ MEA is required for each 10.42 $\mathrm{mg}$ of Pd. Addition of excess of the reagent over the required amount has no adverse effects on the experimental results.

\section{Reliability of the proposed method}

To evaluate the precision and accuracy of the proposed method, determination of palladium at different concentration levels were carried out under optimized experimental conditions. Reproducible and accurate results (Table 2) are obtained in the range 2-20 mg of palladium with the relative error \pm 0.27 and the relative standard deviation $(\mathrm{n}=6)$ not exceeding $0.35 \%$.

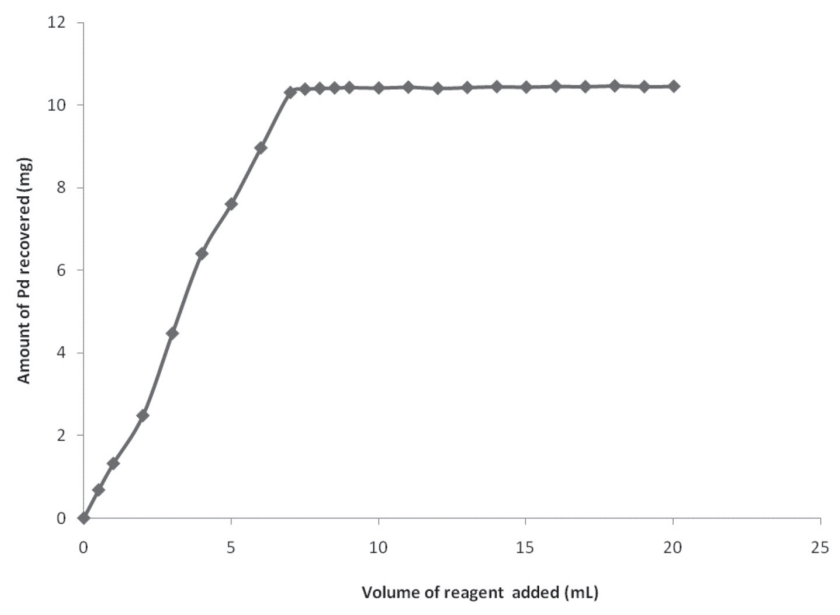

Fig. 1. Effect of $0.2 \%$ 2-mercaptoethylamine on the release of $10.42 \mathrm{mg}$ of Pd(II)

\section{Effect of diverse ions}

The recommended procedure was followed to study the possible interference due to various diverse metal ions with solutions containing $5.21 \mathrm{mg}$ of Pd. The results obtained are presented in Table 3 . The presence of the following ions did not interfere with in the concentration range studied: $100 \mathrm{mg}$ of $\mathrm{Zn}(\mathrm{II})$, $\mathrm{Pb}(\mathrm{II})$; 40mg of $\mathrm{Cd}(\mathrm{II}), \mathrm{Ni}(\mathrm{II}), \mathrm{Co}(\mathrm{II}), \mathrm{Bi}(\mathrm{III}) ; 30 \mathrm{mg}$ of $\mathrm{Fe}(\mathrm{III}), \mathrm{Al}(\mathrm{III}), \mathrm{Ti}(\mathrm{IV})$, $\mathrm{Ce}(\mathrm{III}) ; 25 \mathrm{mg}$ of V(IV), Mo(VI); $20 \mathrm{mg}$ of Pt(IV), Os(VIII), Zr(IV), $\mathrm{Au}(\mathrm{III})$, $\mathrm{As}(\mathrm{V}), \mathrm{U}(\mathrm{VI}) ; 10 \mathrm{mg}$ of $\mathrm{Ru}(\mathrm{III}), \mathrm{Rh}(\mathrm{III}), \mathrm{Ir}(\mathrm{III}), \mathrm{Mn}(\mathrm{II}) ; 100 \mathrm{mg}$ of $\mathrm{SO}_{4}{ }_{4}^{2-}, \mathrm{PO}_{4}^{3-}$, $\mathrm{NO}_{2}^{-}, \mathrm{F}^{-}, \mathrm{Cl}^{-}, \mathrm{Br}$, acetate, oxalate, citrate and tartarate. However, metal ions like $\mathrm{Hg}(\mathrm{II}), \mathrm{Tl}(\mathrm{III}), \mathrm{Cu}(\mathrm{II})$ and $\mathrm{Sn}(\mathrm{IV})$ show interference giving positive error, which is perhaps due to simultaneous release of EDTA from their respective M-EDTA complexes along with Pd(II)-EDTA complex. The interference of $\mathrm{Hg}$ (II) (up to $10 \mathrm{mg}$ ) can be obviated by the addition of $5 \%$ acetyl acetone (5 $\mathrm{mL}$ ) prior to EDTA complexation as secondary masking agent. Similarly, the interference due to $\mathrm{Sn}$ (IV) (up to $10 \mathrm{mg}$ ) can also be avoided by the addition of $2 \% \mathrm{NH} 4 \mathrm{~F}(5 \mathrm{~mL})$ as secondary masking agent.

Table 2. Determination of Pd(II) in palladium chloride solution

\begin{tabular}{|c|c|c|c|}
\hline \multicolumn{2}{|c|}{ Palladium, $\mathrm{mg}$} & \multirow{2}{*}{$\begin{array}{c}\text { Relative } \\
\text { error }(\%)\end{array}$} & \multirow{2}{*}{ RSD $(\%)$} \\
\cline { 1 - 2 } Taken & Found* & 0.00 & 0.33 \\
\hline 1.56 & 1.56 & 0.00 & 0.31 \\
\hline 2.60 & 2.60 & -0.27 & 0.22 \\
\hline 3.65 & 3.64 & -0.19 & 0.15 \\
\hline 5.21 & 5.20 & 0.13 & 0.13 \\
\hline 7.81 & 7.82 & 0.10 & 0.19 \\
\hline 10.42 & 10.41 & -0.06 & 0.10 \\
\hline 15.63 & 15.62 & 0.14 & 0.10 \\
\hline 20.84 & 20.87 & \multicolumn{2}{c}{} \\
\hline
\end{tabular}

*Average of six determinations

$\mathrm{RSD}=$ Relative standard deviation 
Table 3. Determination of Pd(II) in the presence of diverse ions $(\mathrm{Pd}(\mathrm{II})$ taken in solution $=5.21 \mathrm{mg})$

\begin{tabular}{|c|c|c|c|}
\hline Diverse ion & $\begin{array}{l}\text { Quantity added } \\
\text { (mg) }\end{array}$ & $\begin{array}{l}\text { Pd(II) found } \\
\text { (mg) }\end{array}$ & $\begin{array}{c}\text { Relative error } \\
(\%)\end{array}$ \\
\hline $\mathrm{Zn}(\mathrm{II})$ & 100 & 5.21 & 0.00 \\
\hline $\mathrm{Cd}(\mathrm{II})$ & 40 & 5.23 & 0.38 \\
\hline $\mathrm{Ni}(\mathrm{II})$ & 40 & 5.19 & -0.38 \\
\hline $\mathrm{Co}(\mathrm{II})$ & 40 & 5.22 & 0.19 \\
\hline $\mathrm{Pb}(\mathrm{II})$ & 100 & 5.21 & 0.00 \\
\hline $\mathrm{Bi}(\mathrm{III})$ & 40 & 5.18 & -0.58 \\
\hline $\mathrm{Mn}(\mathrm{II})$ & 10 & 5.24 & 0.58 \\
\hline $\mathrm{Fe}(\mathrm{III})$ & 30 & 5.19 & -0.38 \\
\hline $\mathrm{Al}(\mathrm{III})$ & 30 & 5.22 & 0.19 \\
\hline Ti(IV) & 30 & 5.23 & 0.38 \\
\hline V(IV) & 25 & 5.18 & -0.58 \\
\hline $\mathrm{Ce}(\mathrm{III})$ & 30 & 5.19 & -0.38 \\
\hline $\mathrm{Pt}(\mathrm{IV})$ & 20 & 5.24 & 0.58 \\
\hline $\mathrm{Ru}(\mathrm{III})$ & 10 & 5.23 & 0.38 \\
\hline $\mathrm{Rh}(\mathrm{III})$ & 10 & 5.18 & -0.58 \\
\hline Os(VIII) & 20 & 5.23 & 0.38 \\
\hline $\mathrm{Sn}(\mathrm{IV})^{\#}$ & 10 & 5.24 & 0.58 \\
\hline $\mathrm{Zr}(\mathrm{IV})$ & 20 & 5.20 & -0.19 \\
\hline $\mathrm{Au}(\mathrm{III})$ & 20 & 5.23 & 0.38 \\
\hline $\mathrm{As}(\mathrm{V})$ & 20 & 5.18 & -0.58 \\
\hline $\mathrm{Hg}(\mathrm{II})^{\S}$ & 10 & 5.24 & 0.58 \\
\hline $\mathrm{U}(\mathrm{VI})$ & 20 & 5.19 & -0.38 \\
\hline $\operatorname{Ir}(\mathrm{III})$ & 10 & 5.18 & -0.58 \\
\hline $\mathrm{Mo}(\mathrm{VI})$ & 25 & 5.24 & 0.58 \\
\hline $\mathrm{SO}_{4}^{2-}$ & 100 & 5.20 & -0.19 \\
\hline $\mathrm{PO}_{4}^{4-}$ & 100 & 5.19 & -0.38 \\
\hline $\mathrm{NO}_{3}^{-}$ & 100 & 5.24 & 0.58 \\
\hline $\mathrm{F}^{-}$ & 100 & 5.22 & 0.19 \\
\hline $\mathrm{Cl}^{-}$ & 100 & 5.18 & -0.58 \\
\hline $\mathrm{Br}$ & 100 & 5.19 & -0.38 \\
\hline Acetate & 100 & 5.22 & 0.19 \\
\hline Oxalate & 100 & 5.24 & 0.58 \\
\hline Citrate & 100 & 5.23 & 0.38 \\
\hline Tartarate & 100 & 5.19 & -0.38 \\
\hline
\end{tabular}

* Average of three determination

\# Premasked with NH4F and § Premasked with acetyl acetone

\section{Analytical applications of the method}

In order to demonstrate the analytical usefulness of the proposed method, it was applied to the determination of palladium in catalysts, complexes and synthetic alloy samples.

Determination of palladium in catalysts: A known amount of catalyst sample $(0.1-0.2 \mathrm{~g})$ was dissolved in minimum amount of aqua regia. The solution was evaporated to near dryness with the addition of three $5 \mathrm{ml}$ portion of concentrated $\mathrm{HCl}$ to remove the oxides of nitrogen. The cooled solution was filtered, if necessary and diluted to $100 \mathrm{~mL}$ with distilled water in a volumetric flask. Suitable aliquots of this sample solution were analyzed for Pd(II) as per the standard procedure. The results are presented in Table 4.
Table 4. Determination of Palladium in catalysts and complexes

\begin{tabular}{|c|c|c|c|}
\hline Catalyst / Complex & $\begin{array}{c}\text { Palladium } \\
\left.\text { present * }^{*} \%\right)\end{array}$ & $\begin{array}{l}\text { Palladium } \\
\text { found }(\%)\end{array}$ & $\begin{array}{l}\text { RSD } \\
(\%)\end{array}$ \\
\hline Pd- Charcoal Catalyst & 5.14 & 5.16 & 0.40 \\
\hline $\mathrm{Pd}-\mathrm{CaCO} 3$ Catalyst & 9.88 & 9.92 & 0.35 \\
\hline $\mathrm{Pd}(\mathrm{C} 6 \mathrm{H} 7 \mathrm{~N} 3 \mathrm{~S} 2) 2 \mathrm{Cl} 2^{\mathrm{a}}$ & 19.42 & 19.37 & 0.30 \\
\hline $\mathrm{Pd}(\mathrm{C} 7 \mathrm{H} 8 \mathrm{O} 2 \mathrm{~N} 2) 2 \mathrm{Cl}^{\mathrm{b}}$ & 22.09 & 22.01 & 0.35 \\
\hline $\mathrm{Pd}(\mathrm{C} 6 \mathrm{H} 5 \mathrm{~N} 3) 2 \mathrm{Cl} 2^{\mathrm{c}}$ & 25.60 & 25.52 & 0.24 \\
\hline $\mathrm{Pd}(\mathrm{CH} 6 \mathrm{~N} 4 \mathrm{~S}) 2 \mathrm{Cl} 2^{\mathrm{d}}$ & 27.31 & 27.21 & 0.30 \\
\hline $\mathrm{Pd}(\mathrm{CH} 5 \mathrm{~N} 3 \mathrm{~S}) 2 \mathrm{Cl} 2^{\mathrm{e}}$ & 29.59 & 29.48 & 0.40 \\
\hline $\operatorname{Pd}(\mathrm{C} 4 \mathrm{H} 7 \mathrm{O} 2 \mathrm{~N} 2) 2^{\mathrm{f}}$ & 31.61 & 31.55 & 0.24 \\
\hline
\end{tabular}

*Average of three determinations

Determination of palladium in complexes: Some palladium(II) complexes with ligands such as thiophene-2-carboxaldehyde thiosemicarbazone, salicyloyl hydrazide,

1, 2, 3-benzotriazole, thiocarbohydrazide, thiosemicarbazide, and dimethylglyoxime were prepared and purified as per the reported methods 21-24.

A weighed sample of the complex (0.1-0.2g) was carefully decomposed to near dryness with aqua regia. The cooled residue was dissolved in minimum amount of $2 \mathrm{~N} \mathrm{HCl}$ and made up to a mark in a $100 \mathrm{~mL}$ volumetric flask with distilled water. Aliquots of this solution were analyzed for palladium as described and the results obtained are tabulated in Table 4.

Determination of palladium in synthetic mixtures with alloy composition: As certified samples of Oakay alloy, Solder alloy, Dental alloy and Jewellary alloy were not available, synthetic mixtures with the same composition were prepared. Palladium content in these samples was determined by the procedure described and the results are given in Table 5.

Table 5. Determination of palladium in synthetic mixture with alloy composition

\begin{tabular}{|c|c|c|c|}
\hline Alloy & $\begin{array}{c}\text { Synthetic mixture } \\
\text { composition } \\
(\%)\end{array}$ & $\begin{array}{c}\text { Palladium } \\
\text { found }(\%)\end{array}$ & $\begin{array}{c}\text { RSD } \\
(\%)\end{array}$ \\
\hline Oakay alloy & $\begin{array}{c}\text { Pd 10.5; Ni 60.0 } \\
\text { Pt 20.0; V 9.5 }\end{array}$ & 10.54 & 0.40 \\
\hline Solder alloy & $\begin{array}{c}\text { Pd 30.0; Pt 10.0 } \\
\text { Au 60.0 }\end{array}$ & 30.10 & 0.30 \\
\hline Dental alloy & $\begin{array}{c}\text { Pd 34.0; Ni 34.0 } \\
\text { Co 22.0; Au 10.0 }\end{array}$ & 34.12 & 0.35 \\
\hline Jewellary alloy & Pd 50.0; Au 50.0 & 49.86 & 0.24 \\
\hline
\end{tabular}

*Average of three determinations

Pd complex with thiophene-2-carboxaldehyde thiosemicarbazone ${ }^{a}$, salicyloyl hydrazide ${ }^{\mathrm{b}}, \quad$ 1,2,3-benzo-triazole ${ }^{\mathrm{c}}, \quad$ thiocarbohydrazide $^{\mathrm{d}}$, thiosemicarbazide ${ }^{\mathrm{e}}$, dimethylglyoxime. ${ }^{\mathrm{f}}$

\section{CONCLUSIONS}

The proposed method for the complexometric determination of Pd(II) offers advantages of simplicity, rapidity and reasonable selectivity over the other methods. The masking reagent, 2-mercaptoethylamine forms a soluble complex with palladium, releases the EDTA instantaneously at room temperature and tolerates the presence of a number of metal ions without the need for the time consuming steps like heating or solvent extraction. Because no solvent extraction is required, the use of organic solvents, which are generally toxic pollutants, is avoided. In conclusion, the simplicity of the analytical procedure and the use of inexpensive facility make the technique very attractive for a wide spectrum of application. 


\section{ACKNOWLEDGEMENT}

The authors are grateful to the Director and Head of chemistry department, Manipal Institute of Technology, Manipal for providing the laboratory facilities.

\section{REFERENCES}

1.- K. N. Raoot, S. Raoot, Indian J. Chem. 12, 1007, (1974).

2.- K. N. Raoot, S. Raoot, V. G. Vaidya, Indian J. Chem. 18A, 90, (1979).

3.- S. Raoot, K. N. Raoot, Indian J. Technol. 18, 345, (1980).

4 K. N. Raoot, S. Raoot, Talanta 28, 327, (1981).

5.- S. Raoot, K. N. Raoot, V. Lalitha Kumari, Analyst 107, 1382, (1982).

6.- H. R. A. Gadiyar, R. V. Gadag, M. R. Gajendragad, H. V. Sudhakar Nayak,

J. Indian Chem. Soc. 60, 889, (1983).

7.- B. Narayana, M. R. Gajendragad, Microchem. J. 36, 364, (1987).

8.- B. Narayana, M. R. Gajendragad, Curr. Sci. 56, 1279, (1987).

9.- K. N. Raoot, S. Raoot, V. Lalitha Kumari, Analyst 108, 1148, (1983).

10.- A. Nityananda Shetty, R. V. Gadag, M. R. Gajendragad, Indian J. Technol. 27, 224, (1989).

11.- A. Nityananda Shetty, R. V. Gadag, M. R. Gajendragad, Rev. Roum. Chim. 38, 1305, (1993).
12.- B. Narayana, A. Joseph, B. M. Rao, P. Chandra, Doga-Tr. J. Chem. 17, 13, (1993).

13.- Prakash Shetty, A. M. A. Khader, A. Nityananda Shetty, R. V. Gadag, Chem. Acta Turc. 23, 115, (1995).

14.- Prakash Shetty, A. Nityananda Shetty, R. V. Gadag, Indian J. Chem. Technol. 9, 127, (2002).

15.- P. Parameshwara, K. Karthikeyan, A. Nityananda Shetty, Prakash Shetty, Ann. Chim. 96, 125, (2006).

16.- A. I. Vogel, A text book of Quantitative Inorganic Analysis, Longmans, London, 3rd ed., (1964)

17.- D. C. Jicha, D. H. Busch, Inorg. Chem. 1, 872, (1962).

18.- C. W. Schlapfer, K. Nakamoto, Inorg. Chim. Acta 6, 177, (1972).

19.- J. Kragten, Talanta 25, 239, (1978).

20.- Li Yuejin, A. E. Martell, Inorg. Chim. Acta 231, 159, (1995).

21.- K. Mukkanti, K. B. Pandeya, R. P. Singh, Indian J. Chem. 25, 277, (1986).

22.- S. C. Shome, H. R. Das, Anal. Chim. Acta 32, 400, (1965).

23.- G. R. Burns, Inorg. Chem. 7, 277, (1968).

24.- D. S. Mahadevappa, B. T. Gowda, A. S. Ananda Murthy, Curr. Sci. 45, 161, (1976). 